\title{
FACTORS INFLUENCING ADOPTION OF IMPROVED TECHNOLOGY AMONG MAIZE FARMERS IN EKITI STATE NIGERIA
}

\author{
${ }^{* 1}$ Okonji, C. J. and ${ }^{2}$ Awolu, O. T. \\ 1Department of Crop Science and Horticulture, Federal University Oye-Ekiti, Nigeria \\ ${ }^{2}$ Ekiti State Agricultural Development Programme, Zone II, Ikere Ekiti, Nigeria
}

\begin{abstract}
This study was conducted to investigate the factors determining the adoption of improved maize technologies among farmers in Ekiti State, Nigeria. A two-stage sampling technique was used in selecting the respondents for the study. Primary data were collected with the use of a semistructured questionnaire. Descriptive statistics and regression model were used for the analysis. The majority of maize producers in the study area were married, fairly educated and of middle age. The results further showed that the maize farmers were faced with a series of problems such as inadequate credit, bad road network, high-interest rate and lack of collateral. Meanwhile, the adoption of improved maize technology by the farmers was significantly influenced by the use of manure, appropriate planting techniques, use of herbicide, extension visit, and educational status of the farmers. To boost maize production in the study area, the study recommends the provision of single digit loan interest and with facilities, subsidies on farm inputs, construction of roads to production areas, provision of improved maize seeds while farmers should collect a certificate of occupancy on their farmlands to enhance the chances of increasing their access to credit facilities.
\end{abstract}

Keywords: Adoption, Agricultural technology, maize farmers, factors 


\section{INTRODUCTION.}

Technology is said to aim at improving a given situation to a more desirable level. It is also known to assist in doing work easier and faster, saves time and labor (Bonabana-Wabbi, 2002). However, adoption could be seen as the integration of new technology into existing practice and is usually proceeded by a period of 'practice' and some degree of adaptation (Loevinsohn et al., 2013). Fermandez-Cornejo et al. (2007) defined adoption as a mental process by which first knowledge about innovation is acquired to final utilization of it. However, Lawal and Oluloye, (2008) reported that the rate at which innovations are used by farmers could largely be dependent on sensitization, mentoring and demonstration by extension agents. Lawal et al. (2005) documented a 56.7 percent level of adoption of improved varieties of seeds. Nevertheless, Ogunsumi and Ewuola (2005) reported a lower adoption rate of improved crops technology which is as a result of low research and extension outreach to the farmers. Neighborhood effects have been reported by Holloway et al. (2007) and Langyintuo and Mekuria (2008) as an important factor that can greatly influence farmers' adoption decision. They argue that as farmers make technological choices, they are influenced by the behaviour of neighboring farmers or by agroecological characteristics. Another critical factor that can influence farmers' adoption of technology is economic status of the farmer. Muzari and Muvhunzi (2013) reported that wealth will positively influence farmers' adoption decision because of more access to more resources thereby increasing the farmer's ability to bearing the risk.

Ray et al. (2013) identified lack of access to improved varieties and good quality seed, limited access to fertilizers and pesticides, poor dissemination of good agricultural technological practices, mechanization of labour and post-harvest losses, pest and spoilage as some of the challenges limiting the acceptance of improved maize technology by farmers. Therefore, this study aims at assessing the factors influencing the use of improved technologies in maize

production among farmers in Ekiti State, Nigeria. The specific objectives include assessing the socioeconomic characteristics of maize farmers; their awareness of improved maize technology and its influence on maize production as well as the challenges limiting the adoption of improved maize technology in the study area.

\section{Hypothesis of the Study}

H0:There is no significant difference in the impact of level of awareness of improved maize technology on maize production and adoption of maize technology in the study area. 


\section{METHODOLOGY}

\section{Study Area}

The study was carried out in Ekiti State, Nigeria. The state is mainly an upland zone, rising over 250 meters above sea level as it is located entirely within the tropics. The tropical climate of the state is broadly of two seasons: the rainy season (April-October) and dry season (November March). The annual rainfall varies from $1,100 \mathrm{~mm}$ in the Southern areas to $130 \mathrm{~mm}$ in the Northern areas (Adesina, 2008). Most of the land in the area are basically used for agricultural purpose

because $95 \%$ of people in the area engaged in farming either directly or indirectly (Adesina, 2008).

\section{Data Collection}

The method of data collection of the study involved the administration of a semi-structured questionnaire. Information gathered was basically on socio-economic characteristics, information on level of awareness of improved maize technology in the State, levels of adoption of improved technologies and challenges limiting improved maize production in the study area

\section{Sampling Procedure and Sample Size}

A two-stage sampling procedure was used in selecting the respondents that were used for the study. The first stage was the purposive selection of ten out of the sixteen Local Government Areas in the state based on their predominance in maize production according to the information obtained from the Agricultural Development Programme Headquarters at Ikole Ekiti, Nigeria. The Local Government Areas selected for the study included Ise/Orun, Emure, Irepodun/ffelodun, Ado, Ido- Osi, Ikole, Oye, Gboyin, and Ekiti South-West Local Government Area. The second stage involved a random selection of $10 \%$ of farmers from communities at each LGA from a list of registered maize farmers from Ikole Agricultural Development Programme. In all, a total of 150 respondents were selected for the study.

\section{Data Analysis}

The data obtained were subjected to descriptive and regression analyses. 


\section{RESULTS AND DISCUSSION.}

\section{Socio-economic Characteristics of Maize Farmers}

This section presents the results and discussion on the socio-economic characteristics of the respondents. The results are presented in Table 1.

The table shows that farmers who were between ages 41 and 50 years represented $47.3 \%$ of the respondents, $19.3 \%$ were between 31 and 40 years. Respondents who were between 51 and 60 years were $22 \%$ while $7.3 \%$ and $4 \%$ were below 30 years are above 60 years respectively (Table 1). The mean age of a typical maize farmer in the study area was 45 years. This was however higher than the average age of 40 years reported by Idrisa (2009) among farm households in Southern Borno, Nigeria. This result agrees with the findings of Mignouna et al. (2011), Akudugu et al. (2012), and Mbavai (2013) that the farming population in Nigeria generally is relatively dominated by young people which then implies that there is an active labour force available for farming.

Male farmers were more (73.3\%) than the female counterparts (26.7\%). The number of male farmers in this study was similar to the findings of Mbavai (2013) who reported similar dominance of male in a study of cowpea farmers in Musawa LGA of Katsina States. This result is equally similar to the finding of Bamire et al. (2010) et al. (2010) who reported a higher percentage of maize farmers to be male in the dry Savannah of Nigeria.

These household statistics is an important determinant of labour supply especially in rural communities. All things being equal, the greater the number of helping hands a farmer has in his farm which will motivate him to cultivate more hectares (Udemezue, 2014). The majority (55.3\%) of the respondents had a household size of four to six persons. Meanwhile, a typical household in the study area had a household size of five persons. The household size is lower when compared with the values reported by Idrisa (2009) and Mignouna et al. (2011) who reported an average household size of seven and nine persons respectively. 
Table 1: Table Demographic Characteristics of Maize Farmers $(n=150)$

\begin{tabular}{llll}
\hline Variables & Class & Frequency & Percentage \\
\hline Age & $\leq 30$ & 11 & 7.33 \\
& $31-40$ & 29 & 19.33 \\
& $41-50$ & 71 & 47.33 \\
Sex & $51-60$ & 33 & 22.00 \\
Marital Status & $>60$ & 6 & 4.01 \\
& Male & 110 & 73.30 \\
& Female & 40 & 26.70 \\
Educational Status & Single & 13 & 8.70 \\
& Married & 132 & 88.00 \\
& Divorce & 2 & 1.30 \\
Occupation & Separated & 3 & 2.00 \\
& No Formal Education & 29 & 19.30 \\
& Primary & 48 & 32.00 \\
& Secondary & 65 & 43.30 \\
Tertiary & 8 & 5.30 \\
Forming Experience & Farmer & 111 & 74.00 \\
& Civil servant & 12 & 8.00 \\
& Trading & 16 & 10.70 \\
& Taxi driver & 9 & 6.00 \\
& Self Employed & 2 & 1.30 \\
& $\leq 3$ & 24 & 16.00 \\
& $4-6$ & 83 & 55.30 \\
& $7-9$ & 34 & 22.70 \\
& $>9$ & 9 & 6.00 \\
& $5-10$ & 15 & 10.00 \\
& $11-15$ & 55 & 36.70 \\
& $>15$ & 56 & 37.30 \\
& & 24 & 16.00 \\
& & & \\
& & &
\end{tabular}

Source: Field survey (2018)

Results further show that $19.3 \%$ of the maize farmers had no formal education while $32 \%$ had primary education. A large proportion (43.30\%) of the farmers had secondary education while just 
$5.3 \%$ had tertiary education. Since majority of the respondents were well educated, it is expected that the adoption of any technology brought to them would become easier. This is in line with the observation made by Olumba and Rahji (2014) that the educational status of farmers positively influences their adoption of improved technologies. The primary occupation of most $(74 \%)$ of the respondents was farming, $8 \%$ were civil servants, $10.7 \%$ were traders, $6 \%$ were taxi drivers while $1.3 \%$ were self-employed.

\section{Determinants of Awareness of Improved Maize Technology}

Table 2 shows the determinants of awareness of improved maize technology in the study area. Educational levels of farmers, their experience, and frequency of extension visit were the factors that determined the awareness of improved maize technology in the study area. Accordingly, educational status of the respondents had a positive relationship with awareness of improved maize technology (IMT). This implies that farmers with high level of education were aware of IMT than those with a low or no formal education. However, farming experience was observed to have had a negative influence on the awareness of IMT. This implies that farmers with less years of experience were more aware of IMT. Furthermore, the result implies that an increased frequency of extension visits would result in an increased awareness of IMT. Similar findings by Ayinde et al. (2010) reported that the socio-economic characteristics of farmers could influence their awareness of agricultural innovation.

Table 2: Determinants of Awareness of Improved Maize Technology

\begin{tabular}{llllll}
\hline Variables & Coefficient & Std. Error & t-value & Sig. & Pseudo-R \\
\hline (Constant) & 1.01 & 0.24 & 4.21 & 0.00 & \\
Age & 0.02 & 0.07 & 0.29 & 0.45 & \\
Educational Status & 0.13 & 0.06 & $2.17^{*}$ & 0.04 & 0.52 \\
Primary Occupation & 0.01 & 0.03 & -0.33 & 0.97 & \\
Farming Experience & -0.14 & 0.06 & $-2.33^{*}$ & 0.03 & \\
Extension Visit & 0.10 & 0.04 & $2.50^{*}$ & 0.02 & \\
\hline
\end{tabular}

* Significant variables

Source: Field survey (2018) 


\section{Determinants of Adoption of Improved Maize Technology}

Table 3 presents the factors that influenced the adoption of improved maize technology by the farmers in the study area. The table shows that access to credit, good agricultural practices, maturity period and disease resistance were the significant factors that determine the adoption of IMT. The coefficient of determination $\left(R^{2}\right)$ was 0.63 . This indicates that $63 \%$ of the variation in dependent variable was explained by the hypothesized independent variables.

A major factor that determines farmers' adoption of improved maize technology by the farmers was access to credit facilities. It was reported that the majority of the respondents sourced their credit through personal savings. This could be attributed to the fact that most of the farmers did not have the needed collateral demanded by the banks for them to access loans. This finding agrees with the work of Mohamed and Temu (2008) who reported that access to credit loan stimulate the adoption of technology adoption.

Table 3 further shows that the introduction of improved variety as stated by Oladele (2005) is not enough without suitable complementary good agricultural practices such as planting distance, seed dressing, fertilizer application, weed control methods and storage technique to aid the better performance of agricultural technologies.

Table 3: Determinants of Adoption of Improved Maize Technology

\begin{tabular}{llllll}
\hline Variables & Coefficient & Std. Error & t value & Sig. & $\mathbf{R}^{2}$ \\
\hline (Constant) & 1.11 & 0.25 & 4.46 & 0.00 & \\
Land availability & -0.19 & 0.15 & -1.30 & 0.20 & \\
Access to credit & -0.23 & 0.10 & $-2.30^{*}$ & 0.03 & 0.63 \\
Good agricultural practices & -0.32 & 0.12 & $-2.60^{*}$ & 0.03 & \\
Maturity Period & -0.50 & 0.23 & $-2.17^{*}$ & 0.02 & \\
Disease Resistance & -0.23 & 0.10 & $-2.30^{*}$ & 0.03 & \\
\hline
\end{tabular}

* Significant variables

Source: Field survey (2018) 


\section{Challenges Limiting the Adoption of Improved Maize Technology}

This section presents the results of challenges limiting the adoption of improved technology. Some of the problems limiting the adoption of improved technology in maize production are reported in Table 3. About $55 \%$ of the respondents reported that inadequate credit constituted a very serious constraint to accepting improved technology in maize production. Meanwhile, at least $71.3 \%$ of the respondents reported that bad road network constituted a serious constraint to adopting improved maize technology. Inadequate communication network constituted little, serious and very serious constraint to $43.3 \%, 21.3 \%$, and $18 \%$ of the respondents respectively. The result of the study equally indicated that extension services constituted little limitation to the adoption of IMT by $39 \%$ of the farmers while $21 \%$ lamented that inadequate extension services limited its adoption among them (Table 3). Also, inadequate access to inputs constituted a great challenge to the farmers as $21 \%$ of the farmers reported that it was a very serious challenge while $53 \%$ of the farmers opined that it was a serious challenge to them.

Table 3: Challenges Limiting the Adoption of Improved Maize Production Technology

\begin{tabular}{lcccc}
\hline \multicolumn{1}{c}{ Variable } & Not Applicable & Very Serious & Serious & Little Constraint \\
\hline Inadequate Credit & $26(17.33 \%)$ & $82(54.67 \%)$ & $31(20.67 \%)$ & $11(7.33 \%)$ \\
Bad Road Network & $26(17.33 \%)$ & $45(30.00 \%)$ & $62(41.33 \%)$ & $17(11.33 \%)$ \\
Inadequate Communication & $26(17.33 \%)$ & $27(18.00 \%)$ & $32(21.33 \%)$ & $65(43.33 \%)$ \\
Network & $26(17.33 \%)$ & $32(21.33 \%)$ & $34(22.67 \%)$ & $58(38.67 \%)$ \\
Inadequate Extension Service & $26(17.33 \%)$ & $32(21.33 \%)$ & $80(53.33 \%)$ & $12(8.00 \%)$ \\
Inadequate Input Access & $26(17.33 \%)$ & $39(26.00 \%)$ & $72(48.00 \%)$ & $13(8.67 \%)$ \\
High-Interest Rate & $26(17.33 \%)$ & $46(30.67 \%)$ & $54(36.00 \%)$ & $24(16.00 \%)$ \\
Lack of Collateral & $27(18.00 \%)$ & $31(20.67 \%)$ & $78(52.00 \%)$ & $14(9.33 \%)$ \\
Cooperative Pre-Condition & & & &
\end{tabular}

\section{Source: Field survey (2018)}

Furthermore, the high interest rate charged by banks was another major challenge as complained by $48 \%$ of the farmer. A similar challenge faced by the farmers was lack of collateral to source bank loan. This was reported by $31 \%$ of the farmers as being serious though $16 \%$ of the farmers viewed it as a mild challenge. 


\section{CONCLUSION}

The awareness and adoption of improved maize technologies by farmers are determined by a number of socioeconomic and farm-related factors. These include farming experience, educational status, extension visit, access to credit, and good agricultural practices. Others include the maturity period of the maize vis-à-vis the technology and disease resistance. These are coupled with some challenges ranging from institutional to infrastructural bottlenecks.

\section{RECOMMENDATIONS}

Based on the findings of this study, the following interventions are recommended in order to improve adoption of improved maize technology by farmers:

i. Provision of credit facilities to farmers with little or no interest rate. This will assist the maize farmers in getting the needed inputs for their maize farm.

ii. The provision of good road network for easy access of the farmers to the extension workers in disseminating information to the farmers on the availabilities of new technologies.

iii. Complementing the introduction of improved technologies with good agricultural practices will improve the impact of such technologies on farm production.

\section{REFERENCES}

Adegboye, M. A., and Eniolorunda, P. A. (2006, October). Participation of youths in self-help efforts in Jos south local government area of Plateau state. In Proceedings of the 40th Annual Conference of Agricultural Society of Nigeria (ASN) held at National Root Crop Research Institute, Umudike, Abia State, Nigeria. October (pp. 16-20).

Akudugu, M. A., Guo, E., and Dadzie, S. K. (2012). Adoption of modern agricultural production technologies by farm households in Ghana: What factors influence their decisions. Journal of Biology, Agriculture, and Healthcare, 2(3) 152 - 161.

Ayinde, O. E, Adewumi, M. O, Olatunji, G. B., and Babalola, O. A. (2010). Determinants of Adoption of Downy Mildew Resistant Maize by Small-Scale Farmers in Kwara State, Nigeria. Global Journal of Science Frontier Research, 10(1), 32-35

Bamire, A. S., Abdoulaye, T., Sanogo, D., and Langyintuo, A. (2010). Characterization of maize producing households in the Dry Savanna of Nigeria. Country Report - Nigeria.: IITA Ibadan, Nigeria 46 pp.

Bonabana-Wabbi, J. (2002). Assessing factors affecting adoption of agricultural technologies: The case of Integrated Pest Management (IPM) in Kumi District, Eastern Uganda. 
Unpublished M.Sc Thesis in the Department of Agricultural and Applied Economics, Virginia Polytechnic Institute and State University, Blacksburg, Virginia.

Fernandez-Cornejo, J., Mishra, A. K., Nehring, R. F., Hendricks, C., Southern, M., and Gregory, A. (2007). Off-farm income, technology adoption, and farm economic performance: United States Department of Agriculture, Economic Research Service of market participation among Filipino smallholders. Journal of Agricultural Economics, 58(1), 37-60.

Holloway, G., Lapar, M., and Lucila, A. (2007). How big is your neighbourhood? Spatial implications of market participation among Filipino smallholders. Journal of Agricultural Economics, 58(1), 37-60.

Idrisa, Y. I (2009). Analysis of the determinant of soybean production technology adoption by farmers in southern Borno State. Unpublished Ph.D. Dissertation submitted to the School of Postgraduate Studies, University of Maiduguri, Borno-Nigeria.

International Institute of Tropical Agriculture., (IITA) (2007): Doubling maize production in Nigeria. Retrieved from https://www.iita.org/news-item/igerian-government-receives-blueprintdoubling-maize-production/

Lawal, A.F., Liman, A, and Lakpenet, T. (2005). Adoption of yam minisett Technology by farmers in Niger State, Southern Guinea Savannah, Nigeria. Nigerian Journal of Agriculture, Food and Environment, 10 (1), $65-71$

Lawal, J. O., and Oluyole, K. A. (2008). Factors influencing adoption of research results and agricultural technologies among cocoa farming households in Oyo State, Nigeria. International Journal of Sustainable Crop Production, 3(5), 10-12.

Loevinsohn, M., Sumberg, J., Diagne, A., and Whitfield, S. (2013). Under what circumstances and conditions does adoption of technology result in increased agricultural productivity? A Systematic Review. Institute of Development Studies, Brighton, UK. 31 pp.

Mbavai, J. J. (2013). An assessment of the effectiveness of the Sudan Savanna Taskforce project in adoption and diffusion of improved cowpea varieties in selected communities in Musawa Local Government Area of Katsina State. Unpublished Msc thesis submitted to the Department of Adult Education and Community Services, Faculty of Education, Bayero University Kano.

Mignouna, B., Manyong, M., Rusike, J., Mutabazi, S., and Senkondo, M. (2011). Determinants of Adopting Imazapyr-Resistant Maize Technology and its Impact on Household Income in Western Kenya. AgBioforum, 14(3), 158-163. 
Mohamed, K. S., and Temu, A. E. (2008). Access to credit and its effect on the adoption of agricultural technologies: the case of Zanzibar. African Review of Money Finance and Banking, 45-89.

Muzari, W., Gatsi, W., \& Muvhunzi, S. (2012). The impacts of technology adoption on smallholder agricultural productivity in sub-Saharan Africa: A review. Journal of Sustainable Development, 5(8), 69-77

Ogunsumi, L. O., and Ewuola, S. O. (2005). Adoption behaviour of farmers in southwest, Nigeria: the case of soybean farmers. Journal of Central European Agriculture, 6(4), 415-426.

Oladele, O. I. (2005). A Tobit analysis of propensity to discontinue adoption of agricultural technology among farmers in Southwestern Nigeria. Journal of Central European Agriculture, 6(3), 249-254.

Olumba, C. C., and Rahji, M. A. Y. (2014). An Analysis of the Determinants of the Adoption of Improved Plantain Technologies in Anambra State, Nigeria. Journal of Agriculture and Sustainability, 5(2).232-245

Ray, D. K., Mueller, N. D., West, P. C., \& Foley, J. A. (2013). Yield trends are insufficient to double global crop production by 2050. PloS one, 8(6), e66428.

Udemezue, J. C. (2013). Adoption of Faro-44 rice production technologies by farmers in Anambra State. Unpublished M.Sc thesis submitted in the Department of Agricultural Extension, University of Nigeria, Nsukka. 